Orthopäde $2021 \cdot 50: 750-757$

https://doi.org/10.1007/s00132-020-04008-1

Published online: 21 October 2020

(c) The Author(s) 2020

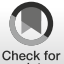

Christian Lycke' Dirk Zajonz $^{2}$ - Alexander Brand ${ }^{1} \cdot$ Torsten Prietzel $^{2} \cdot$ ChristophE. Heyde ${ }^{1} \cdot$ Andreas Roth $^{1} \cdot$ Mohamed Ghanem ${ }^{1}$

${ }^{1}$ Klinik für Orthopädie, Unfallchirurgie und Plastische Chirurgie, Universitätsklinikum Leipzig, Leipzig, Germany

${ }^{2}$ Klinik für Orthopädie, Unfall- und Wiederherstellungschirurgie, Zeisigwaldkliniken Bethanien Chemnitz, Chemnitz, Germany

\title{
Metaphyseal sleeves in arthroplasty of the knee
}

\section{A suitable tool in management of major metaphyseal bone loss}

press-fitted into the medulla of the femur and/or tibia and provide additional stability in the diaphysis.

This study was carried out to examine the clinical outcome following revision arthroplasty of the knee joint and severe arthrosis with metaphyseal bone defects and instability using metaphyseal sleeves. We analyzed the results based on established scores and recorded the complications occurring with revision arthroplasty.

\section{Material and methods}

Prior to conducting this study a positive vote of the local ethics committee (Votum-No. 236/19-ek) was obtained. From May 2011 to March 2019, we identified patients who had undergone aseptic arthroplastic surgery of the knee with significant metaphyseal bone defects of the femur and/or tibia ( $\bullet$ Fig. 1) or major proximal diaphyseal defects due to inlay wear (• Fig. 2). We evaluated patient data and conducted a clinical and radiological follow-up examination of the patients.

In order to have a homogeneous study group, we included patients with revision arthroplasty of the knee and metaphyseal bone defects grade III according to the AORI classification [9]. The major tibial and femoral bone deficiency situation and instability were intraoperatively confirmed as grade III. Patients with metaphyseal defects of class AORI I and II and patients with positive results for pathogens in the microbiological probe after explantation were excluded (• Fig. 3). Furthermore, we included patients with primary varus gonarthrosis who had primary major metaphyseal bone defects due to severe osteoporosis along with significant deformity and hence were treated primarily with semiconstrained or constrained total knee arthroplasty.

Altogether 16 patients ( 9 females and 7 males) were included: 12 patients after revision arthroplasty of the knee and 4 patients with primary arthrosis along with severe metaphyseal bone defects and varus deformity. In all cases we performed surgery using an endoprosthesis COMPLETE ${ }^{m}$ revision knee system with the tibial and femoral metaphyseal sleeves LCS $^{\circledR}$ valgus-varusconstrained VVC or S-ROM ${ }^{\circledast}$ rotating hinge knee system (DePuy International,

\begin{tabular}{|ll}
\hline Abbreviations \\
\hline AORI & $\begin{array}{l}\text { Anderson Orthopedic Research } \\
\text { Institute }\end{array}$ \\
\hline HSS & $\begin{array}{l}\text { Hospital for Special Surgery score } \\
\text { system }\end{array}$ \\
\hline KSS & Knee Society Score \\
\hline LCS & Low contact stress \\
\hline NRS & Numerical Rating Scale \\
\hline SPSS & $\begin{array}{l}\text { Statistical Package for the Social } \\
\text { Sciences }\end{array}$ \\
\hline TKA & Total Knee Arthroplasty \\
\hline
\end{tabular}



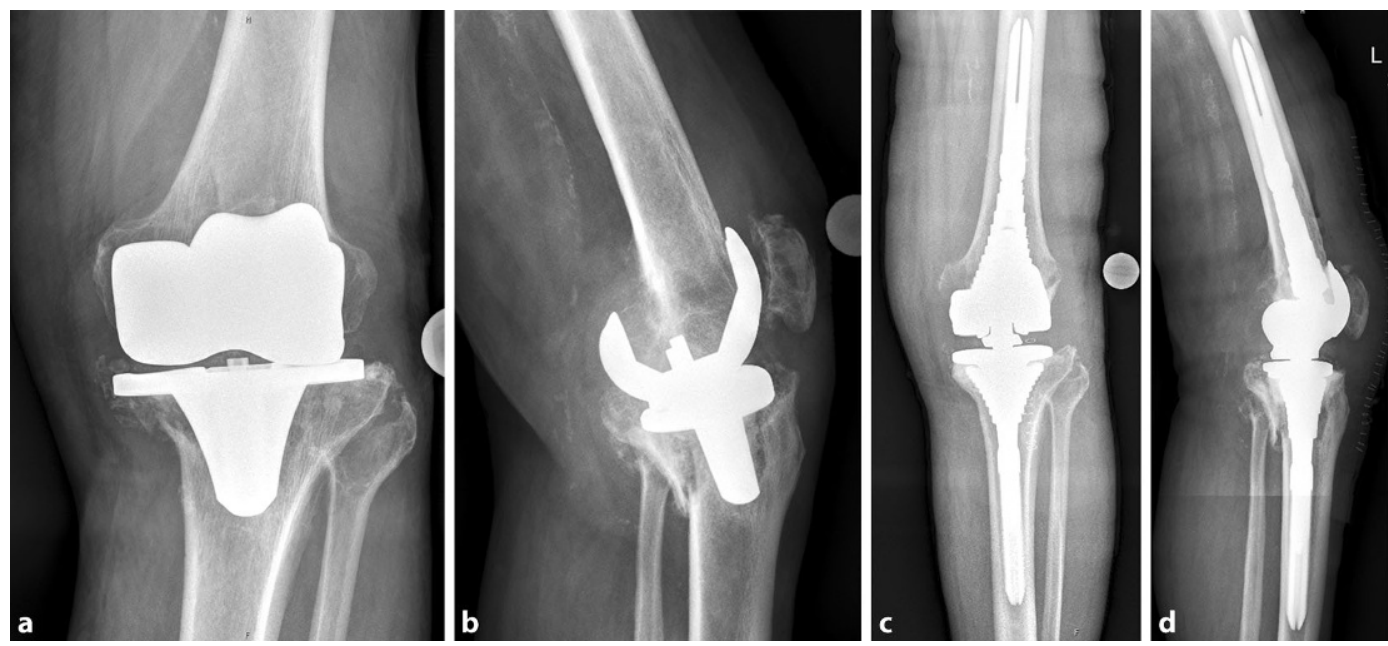

Fig. $1 \Delta$ X-ray radiographs (a anteroposterior and $\mathbf{d}$ lateral view) of a patient with aseptic KTEP loosening and simultaneous tibial and femoral periprosthetic fractures with metaphyseal bone loss after explantation of the primary components. Significant osteoporosis was identified during surgery (courtesy of the Department of Diagnostic and Interventional Radiology, University Hospital of Leipzig, all rights reserved).c, $\mathbf{d}$ The same patient (c anteroposterior, $\mathbf{b}$ lateral view) after removal of the loosened total knee components and implantation of a rotating hinge knee revision system with metaphyseal sleeves (courtesy of the Department of Diagnostic and Interventional Radiology, University Hospital of Leipzig, all rights reserved)

Leeds, UK). Clinical and radiological follow-up examinations were carried out. We evaluated the knee score according to Ranawat and Shine (HSS) and the functional and clinical knee society score according to Insall (KSS) [15]. Furthermore, we estimated the Numerical Rating Scale to compare the pain level and the preoperative and postoperative range of motion as well as the number of complications. The current radiological images were evaluated focusing on signs of loosening (e.g. radiolucent lines, changes of positioning). The data were evaluated with SPSS (IBM, Armonk, NY, USA) and Microsoft Excel 2019 (Microsoft, Redmond, WA, USA).

\section{Results}

The average follow-up period was 79.5 months in the primary arthroplasty group and 31 months in the revision arthroplasty group. The average age at surgery of the patients was $76.5 \pm 12$ years and $79 \pm 7$ years, respectively ( $\bullet$ Tables 1 and 2). The median duration of surgery in the primary group was $259 \pm 26 \mathrm{~min}$ and in the revision group $151 \pm 57 \mathrm{~min}$.

The median HSS score in the cohort with primary arthroplasty at the last time of examination (median follow-up 79.5 months, range $63-93$ months) was 84
$( \pm 11)$ and in the cohort with revision arthroplasty $73( \pm 18)$ (median followup 31 months, range 24-94 months) and the KSS was $83( \pm 23)$ and $55( \pm 34)$, respectively. According to the HSS $50 \%$ of the patients achieved an excellent result in the primary arthroplasty group and $25 \%$ in the revision group. $25 \%$ received a "good" result respectively $33 \%$ in the revision group and $25 \%$ received a "mediocre" result respectively $17 \%$. Only three patients were considered to have an insufficient result (• Table 3).

Postoperative pain was significantly reduced in both groups compared to preoperative pain $(2.7 / 10 \pm 1.9$ postoperative versus $7.7 / 10 \pm 1.4$ preoperative, $p<0.001$ ) (• Fig. 4). The median range of motion was $112^{\circ}$ flexion (median $\pm 24^{\circ}$ ) in the primary arthroplasty group and $95^{\circ}$ (median; $\pm 26.3^{\circ}$ ) in the revision group. An extension deficit was observed in three patients $\left(18.75 \%, 30^{\circ}-5^{\circ}\right.$ extension deficit) and two patients (11.8\%) showed postoperative swelling of the knee joint, of whom one suffered from chronic lymphedema ( $\bullet$ Tables 1 and 2 ).

Four patients had no specific postoperative complications (25\%), two out of these four underwent previous knee surgery (50\%). Four patients showed prolonged wound healing postoperatively (25\%), which was treated con- servatively and did not lead to septic changes. A postoperative hematoma had to be treated by puncture or surgical revision in two cases (12.5\%). Of the patients two suffered from recurrent effusions until the last follow-up (12.5\%). In one case $(6.25 \%)$ a patellar tendon rupture occurred, which had to be treated with a patellar tendon graft 17 months after the initial revision operation. After 44 months the same patient received a retropatellar replacement due to retropatellar arthrosis. One patient $(6.25 \%)$ with a known peroneal lesion showed increasing weakness of dorsiflexion and toe lifter from muscular strenght grade $3 / 5$ (flexion against gravity feasible) according to Janda to 1/5 (muscular twitches) 14 days postoperatively and was treated conservatively. At the last follow-up the lesion was still present with only slight improvement (Janda 2/5 flexion under suspension of gravity feasible).

Two independent examiners found no radiological signs of aseptic loosening such as radiolucent zones, endoprosthetic shift or dislocation or localized cortical hypertrophy [16] in any of the cases $(0 \%)$. 
Orthopäde 2021 · 50:750-757 https://doi.org/10.1007/s00132-020-04008-1

(c) The Author(s) 2020

C. Lycke · D. Zajonz · A. Brand · T. Prietzel · C. Heyde · A. Roth · M. Ghanem

Metaphyseal sleeves in arthroplasty of the knee. A suitable tool in management of major metaphyseal bone loss

\section{Abstract}

Background. This study examined the clinical outcome following revision arthroplasty of the knee joint and severe arthrosis with metaphyseal bone defects and instability using metaphyseal sleeves. We analyzed the results based on established scores and recorded the complications occurring on revision arthroplasty.

Material and methods. Patients with revision arthroplasty of the knee and metaphyseal bone defects grade III according to the Anderson Orthopedic Research Institute (AORI) classification were included (16 patients, 9 females and 7 males). In all cases, surgery was performed using an endoprosthesis COMPLETE $^{\mathrm{TM}}$ revision knee system with metaphyseal sleeves.
Results. All patients had a significant reduction in pain level after revision surgery. The median HSS score in the cohort with primary arthroplasty was 84 and in the cohort with revision arthroplasty 73 and the KSS was 83 and 55, respectively. According to the HSS an excellent result was achieved by $50 \%$ of the patients in the primary arthroplasty group and $25 \%$ in the revision group. Only three patients were considered to have an insufficient result. Postoperative pain was significantly reduced in both groups. The median ROM was $112^{\circ}$ flexion in the primary arthroplasty group and $95^{\circ}$ in the revision group. An extension deficit was observed in three patients and four patients showed prolonged wound healing postoperatively
(25\%), which was treated conservatively and did not lead to septic changes.

Conclusion. The use of metaphyseal sleeves in patients with bone defects is a suitable instrument with no negative impact on the outcome both in primary and revision arthroplasty. Further studies with larger study groups and analysis of long-term results after use of such endoprosthetic components should be conducted.

Keywords Retrospective study - Revision arthroplasty . Osteoarthritis, knee · Complications · Aseptic loosening

\section{Metaphysäre Sleeves in der Kniegelenkendoprothetik. Ein geeignetes Instrument für die Behandlung eines schweren metaphysären Knochenverlusts}

\section{Zusammenfassung}

Hintergrund. Diese Arbeit untersucht das klinische Ergebnis nach Verwendung sog. Sleeves (Hülsen) in der aseptischen Revisionsendoprothetik des Kniegelenks sowie bei schwerster Arthrose mit metaphysären Knochendefekten und Instabilität. Die Ergebnisse wurden auf der Grundlage etablierter Scores analysiert und die aufgetretenen Komplikationen erfasst.

Material und Methoden. Es wurden Patienten mit Revisionsendoprothesen des Knies und metaphysären Knochendefekten mit einem Klassifizierungsgrad III nach dem Anderson Orthopedic Research Institute (AORI) eingeschlossen (16 Patienten; 9 weiblich und 7 männlich). In allen Fällen wurde die Operation mit dem Endoprothesen-Revisionssystem COMPLETE $^{\mathrm{TM}}$ mit metaphysären Sleeves durchgeführt.
Ergebnisse. Bei allen Patienten konnte eine signifikante Reduktion der Schmerzen durch die Revisionsoperation erzielt werden. Der Medianwert des HSS-Scores lag bei 84 in der Gruppe der primär Operierten und bei 73 in der Gruppe mit Voroperationen, der Wert des KSS-Scores betrug 83 bzw. 55. Entsprechend des HSS-Scores erhielten 50\% der Patientengruppe der Erstoperierten ein "ausgezeichnetes" Ergebnis und $25 \%$ in der Revisionsgruppe. Nur 3 Patienten wurden insgesamt als "unzureichend" eingestuft. Die postoperativen Schmerzen waren im Vergleich zu den präoperativen in beiden Gruppen signifikant reduziert. Der mediane Bewegungsumfang (ROM) betrug $112^{\circ}$ Beugung in der primär operierten Gruppe bzw. $95^{\circ}$ in der Revisionsgruppe. Bei 3 Patienten wurde ein Extensionsdefizit beobachtet und 4 Patienten zeigten postoperativ eine prolongierte Wundheilung (25\%), die konservativ behandelt wurde und nicht zu septischen Revisionseingriffen führte. Schlussfolgerung. Metaphysären Sleeves stellen bei Patienten mit Knochendefekten ein geeignetes Instrument dar, das sowohl bei Primäreingriffen als auch bei Revisionsoperationen nicht zu unterlegenen Ergebnissen bei Patienten mit schweren metaphysären knöchernen Defekten führt. Weitere Studien mit größeren Studiengruppen und die Analyse der Langzeitergebnisse nach dem Einsatz solcher endoprothetischer Komponenten sollten durchgeführt werden.

\section{Schlüsselwörter}

Retrospektive Studie · Revisionsarthroplastik . Gonarthrose - Komplikationen - Aseptische Lockerung

\section{Discussion}

The most remarkable results of this retrospective follow-up examination were the significant postoperative pain relief and the absence of postoperative loosening. The average value of the HSS was $84( \pm 11)$ and in the cohort with revision arthroplasty $73( \pm 18)$ and can overall be considered as a good result. Rosso et al. obtained comparable results with an HSS of $82.5( \pm 8.4)$ [19]. The KSS was $83( \pm 23)$ and $55( \pm 34)$, respectively. Compared with reports in the literature, the results are similar to the survey by Graichen et al. $(68.8 \pm 23.3)$ [11] and Bugler et al. $(58.1 \pm 33.1)$ [7].
One specification of our study is the investigation of sleeve-stem systems in purely aseptic revision arthroplasty of the knee joint. According to our literature research, no prior study has exclusively evaluated the outcome after aseptic revision arthroplasty of the knee using metaphyseal sleeve-stem systems. The use of metaphyseal sleeves has already been in- 

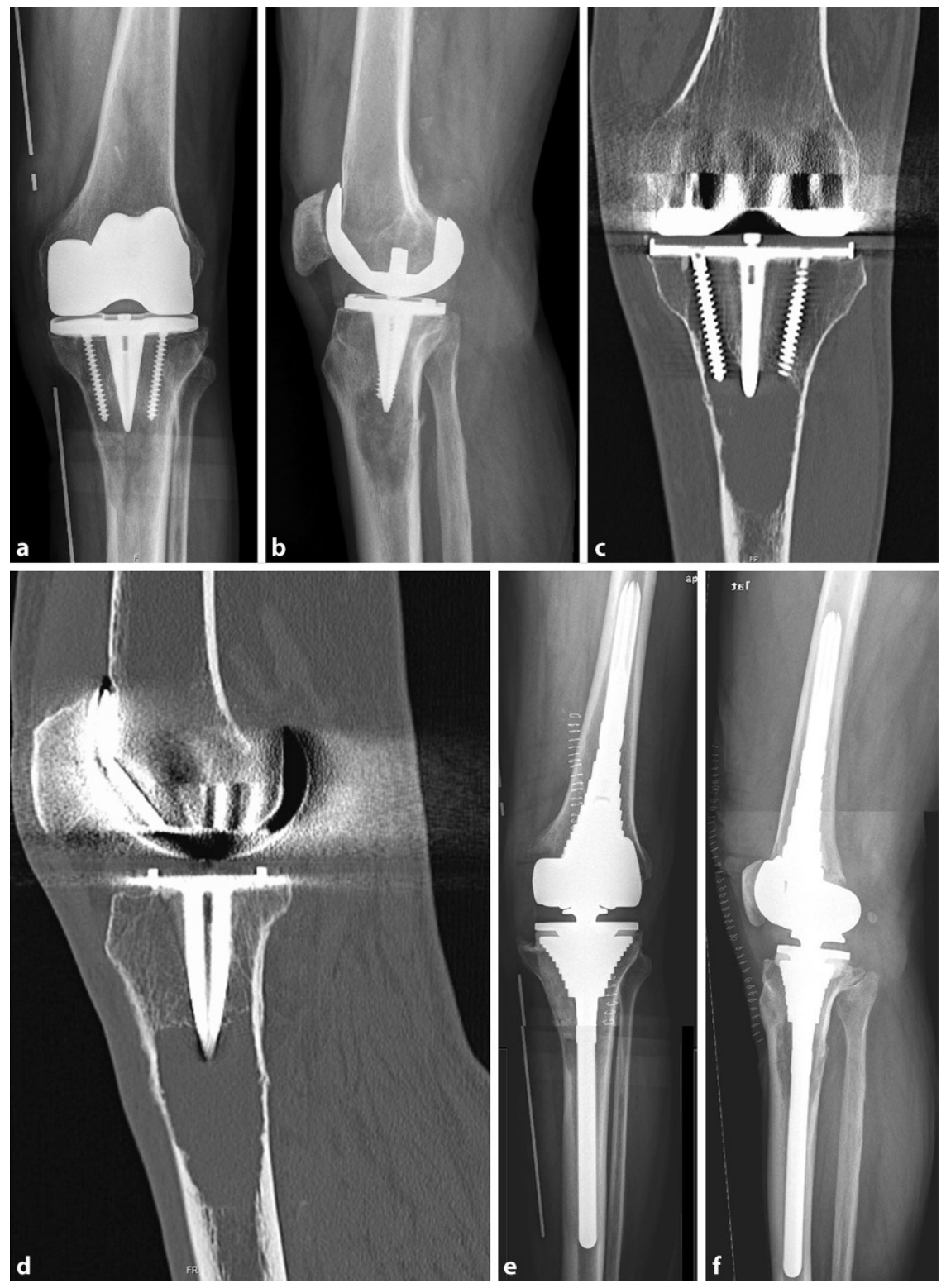

Fig. $2 \Delta$ X-ray radiographs (a anteroposterior, b lateral view) of aseptic loosening of primary total knee components with major osteolytic changes in the proximal tibial diaphysis due to wear of the inlay (particle disease) (courtesy of the Department of Diagnostic and Interventional Radiology, University Hospital of Leipzig, all rights reserved). c, $\mathbf{d}$ Prior to surgery (c anteroposterior, $\mathbf{d}$ lateral view) a CT scan was performed to confirm the diagnosis and rule out malignant transformation (courtesy of the Department of Diagnostic and Interventional Radiology, University Hospital of Leipzig, all rights reserved). $\mathbf{e}, \mathbf{f}$ The same patient (e anteroposterior, $\mathbf{f}$ lateral view) after implantation of a rotating hinge knee revision system with metaphyseal sleeves (courtesy of the Department of Diagnostic and Interventional Radiology, University Hospital of Leipzig, all rights reserved)

vestigated in other studies with different follow-up times, patient numbers and results with septic as well as aseptic cases ([2, 5, 8, 14]; - Table 4). When comparing clinical and functional scores, the results of the present study are comparable with those of other studies $[4,12]$.

Another specific feature of our study is that all patients included in the study had severe metaphyseal bone defects of the AORI classification grade III $[9,21]$. This distinguishes this patient population from other studies that included patients of all AORI grades in their study.

In the literature there are different results concerning septic or aseptic loosening of sleeve-stem systems. For example, results of the studies by Graichen et al.,
Bugler et al. and Watters et al. [7, 11, 24] showed loosening rates below $10 \%$. Rosso et al. [19] documented a loosening rate of up to $41.5 \%$. Graichen et al. [11] and Bugler et al. [7] had similar follow-up periods compared to this study (3.6 years, range 2-6.2 years and 3.2 years, range 2-5.1 years, respectively). Watters et al. [24] had a follow-up period of 5.3 years (range 2-9.6 years). Graichen et al. examined 121 patients, Watters et al. 108 and Bugler et al. 35; however, Rosso et al. [19] only used sleeves in patients with defects of AORI classification III, but also included patients with preoperative infections, which was an exclusion criterion in the present study. The absence of loosening in our work could then be an explanation of the fact that the pain level of the patients in this study was significantly lower after surgery was performed.

A limitation of this study lies in the small number of cases $(n=16)$; however, no study group with purely aseptic replacement surgery using sleeves for AORI III defects in revision knee arthroplasty has ever been investigated. Metaphyseal sleeves showed no negative impact on patient outcome: pain levels were significantly reduced (NRS preoperative $7.7 \pm 1.4$ vs. postoperative $2.7 \pm 1.9 ; p>0.001)$, the median range of motion was $112^{\circ}$ and $95^{\circ}$ flexion (median; $\pm 27^{\circ}$ ), repectively and extension deficit was observed only in three patients (18.75\%; $30^{\circ}-5^{\circ}$ extension deficit). Two patients $(12.5 \%)$ showed postoperative swelling of the knee joint and no patient suffered from postoperative instability. It is remarkable that patients with primary arthroplasty had a significantly longer operating time but, in the end, slightly better average scores in HSS and KSS and $50 \%$ of them showed no specific complication at all.

There are different ways of treating metaphyseal bone defects in revision arthroplasty of the knee, for example the use of bone cement for defect augmentation. This is only recommended for patients with AORI grades I and II [23]. Likewise, so-called wedges, bone chips or autologous bone blocks can be used as augmentation for bone defects, but these show only moderate long-term 
Table 1 Preoperative profiles of patients with a list of previous operations, age, pre-existing condition category (ASA classification according to the American Society of Anesthesiologists), duration of surgery and outcome (ROM range of motion, pain level and complications). The mean flexion was $95^{\circ}$. Almost every patient was able to perform a full extension $\left(0^{\circ}\right)$.

\begin{tabular}{|c|c|c|c|c|c|c|c|c|}
\hline Patient & $\begin{array}{l}\text { Age } \\
\text { (years) }\end{array}$ & $\begin{array}{l}\text { Previous knee } \\
\text { surgery }(n)\end{array}$ & ASA & $\begin{array}{l}\text { ROM (ex/ } \\
\text { zero/flex) }\end{array}$ & $\begin{array}{l}\text { Pain level } \\
\text { preoperative }\end{array}$ & $\begin{array}{l}\text { Pain level post- } \\
\text { operative }\end{array}$ & Complications & $\begin{array}{l}\text { Operation } \\
\text { duration (min) }\end{array}$ \\
\hline 1 & 92 & 1 & 3 & $0 / 0 / 90^{\circ}$ & 8 & 1 & Recurring effusions & 120 \\
\hline 2 & 80 & 1 & 3 & $0 / 0 / 50^{\circ}$ & 7 & 3 & Prolonged wound healing & 275 \\
\hline 3 & 68 & 1 & 3 & $0 / 30 / 120^{\circ}$ & 8 & 2 & - & 257 \\
\hline 4 & 76 & 1 & 3 & $0 / 0 / 110^{\circ}$ & 8 & 2 & - & 80 \\
\hline 5 & 90 & 1 & 3 & $0 / 0 / 30^{\circ}$ & 8 & 6 & Prolonged pain & 118 \\
\hline 6 & 78 & 1 & 3 & $0 / 0 / 90^{\circ}$ & 10 & 6 & Prolonged pain & 158 \\
\hline 7 & 74 & 1 & 2 & $0 / 0 / 100^{\circ}$ & 8 & 2 & Recurring effusions & 126 \\
\hline 8 & 88 & 1 & 3 & $0 / 0 / 90^{\circ}$ & 8 & 5 & Prolonged wound healing & 147 \\
\hline 9 & 75 & 7 & 3 & $0 / 5 / 50^{\circ}$ & 5 & 2 & Retropatellar arthrosis & 240 \\
\hline 10 & 78 & 1 & 3 & $0 / 0 / 100^{\circ}$ & 5 & 0 & Prolonged wound healing & 151 \\
\hline 11 & 87 & 1 & 3 & $0 / 0 / 100^{\circ}$ & 8 & 2 & Postoperative hematoma & 160 \\
\hline 12 & 80 & 1 & 3 & $0 / 0 / 100^{\circ}$ & 7 & 1 & $\begin{array}{l}\text { Exacerbation of partial } \\
\text { peroneal paralysis }\end{array}$ & 151 \\
\hline Mean & $79 \pm 6.9$ & - & 3 & $95^{\circ}$ & 8 & 2 & - & $151 \pm 27.7$ \\
\hline
\end{tabular}

Table 2 Preoperative profiles of patients with primary operation, age, pre-existing condition category (ASA classification according to the American Society of Anesthesiologists), duration of surgery and outcome (ROM range of motion, pain level and complications)

\begin{tabular}{|c|c|c|c|c|c|c|c|}
\hline Patient & Age (years) & ASA & $\begin{array}{l}\text { ROM (ex/ } \\
\text { zero/flex) }\end{array}$ & $\begin{array}{l}\text { Pain level preopera- } \\
\text { tive }\end{array}$ & $\begin{array}{l}\text { Pain level postopera- } \\
\text { tive }\end{array}$ & Complication & $\begin{array}{l}\text { Operation duration } \\
\text { (min) }\end{array}$ \\
\hline 1 & 58 & 2 & $0 / 0 / 60^{\circ}$ & 8 & 4 & Lymphedema & 248 \\
\hline 2 & 82 & 3 & $0 / 5 / 120^{\circ}$ & 6 & 0 & - & 270 \\
\hline 3 & 71 & 3 & $0 / 0 / 115^{\circ}$ & 9 & 3 & - & 284 \\
\hline 4 & 90 & 3 & $0 / 0 / 110^{\circ}$ & 10 & 2 & $\begin{array}{l}\text { Prolonged wound } \\
\text { healing }\end{array}$ & 215 \\
\hline Mean & $76.5 \pm 12$ & 3 & $112.5^{\circ}$ & 8.5 & 2.5 & - & $259 \pm 26$ \\
\hline
\end{tabular}

\begin{tabular}{|c|c|c|c|}
\hline Parameter & Median & Standard deviation & Range \\
\hline \multicolumn{4}{|c|}{ Flexion and pain levels in revision arthroplasty } \\
\hline HSS & 73 & \pm 18.0 & $42-95$ \\
\hline Clinical KSS & 53 & \pm 24 & $5-87$ \\
\hline Functional KSS & 55 & \pm 34 & $0-100$ \\
\hline ROM flexion & $95^{\circ}$ & $\pm 26.3^{\circ}$ & - \\
\hline Preoperative pain level & 8 & \pm 1.3 & $5-10$ \\
\hline Postoperative pain level & 2 & \pm 1.9 & $0-6$ \\
\hline Follow-up (months) & 31 & - & $24-94$ \\
\hline \multicolumn{4}{|c|}{ Flexion and pain levels in primary arthroplasty } \\
\hline HSS & 84 & \pm 11.0 & $66-95$ \\
\hline Clinical KSS & 72 & \pm 22 & $32-87$ \\
\hline Functional KSS & 82.5 & \pm 23 & $40-100$ \\
\hline ROM flexion & 112.5 & $\pm 24^{\circ}$ & - \\
\hline Preoperative pain level & 8.5 & \pm 1.4 & $6-10$ \\
\hline Postoperative pain level & 2.5 & \pm 1.9 & $0-4$ \\
\hline Follow-up (months) & 79.5 & - & $63-93$ \\
\hline
\end{tabular}

results [13]. Especially in the mentioned case 1 (• Fig. 1) the use of a so-called metaphyseal cone would be another adequate option for treating metaphyseal defects like this [19]. These cones may be also useful to achieve a good metaphyseal fixation in the presence of poor bone quality. The choice for one or the other option depends on the surgeon's experience, type, size and location of the defect and on the quality of the bone. For larger bone defects, the use of distal femoral replacement sets should be mentioned; however, the use of such megaimplants is associated with significantly higher intraoperative and perioperative complication rates [26].

Overall, the results of this study as well as comparable studies [3] indicate a positive benefit of metaphyseal fixation using 


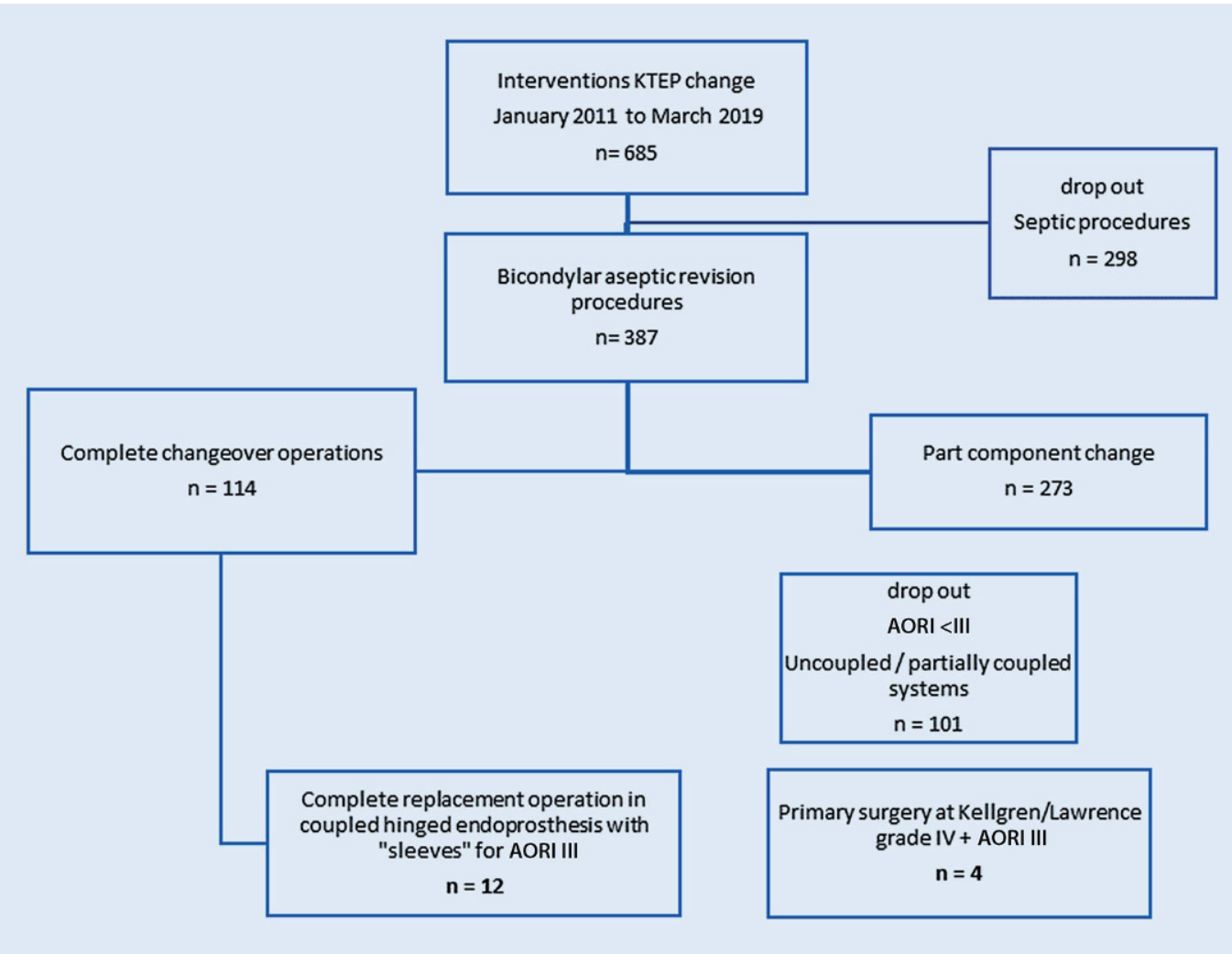

Fig. $3<$ Overview of the patient selection process. Out of a total of 685 patients, 12 patients met the inclusion criteria, 4 patients with primary implants were additionally included TKA total knee arthroplasty, AORI Anderson Orthopedic Research Institute. All patients with primary surgery had the most severe grade IV arthrosis after Kellgren and Lawrence classification[17]

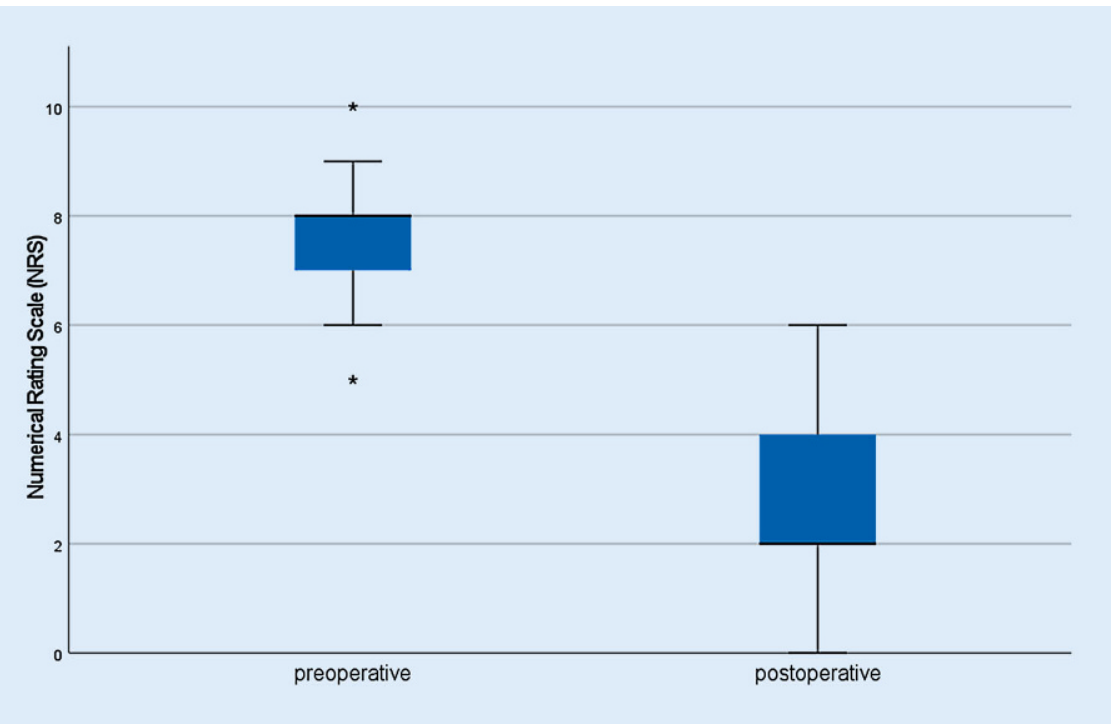

Fig. $4 \Delta$ Overview of preoperative and postoperative pain levels using the numerical rating scale (NRS). Pain reduction was significant $(p<0.001)$ : median preoperative pain level was $7.7 / 10( \pm 1.4)$ shown on the left side, median postoperative pain level was $2.7 / 10( \pm 1.9)$ on the NRS shown on the right side. The Asterisk represent the statistical outliers 
Table 4 Overview of comparable works and study results. The results of the HSS and KSS in this study were seperated into primary and revision TKA

\begin{tabular}{|c|c|c|c|c|c|c|c|c|}
\hline Reference & Type of study & $\begin{array}{l}\text { Patients } \\
\text { (n) }\end{array}$ & $\begin{array}{l}\text { Median } \\
\text { follow-up } \\
\text { (years) }\end{array}$ & $\begin{array}{l}\text { Min. } \\
\text { follow-up } \\
\text { (years) }\end{array}$ & $\begin{array}{l}\text { Max. } \\
\text { follow-up } \\
\text { (years) }\end{array}$ & HSS & $\begin{array}{l}\text { Clinical } \\
\text { KSS }\end{array}$ & $\begin{array}{l}\text { Functional } \\
\text { KSS }\end{array}$ \\
\hline Alexander et al. [2] & Retrospective & 28 & 2.8 & 2 & 4.3 & - & 94 & - \\
\hline Barnett et al. [4] & Retrospective & 34 & 3.1 & 2 & 5.1 & - & $\begin{array}{l}88.7 \\
( \pm 13.1)\end{array}$ & $75( \pm 18.7)$ \\
\hline Bugler et al. [7] & Retrospective & 35 & 3.2 & 2 & 5.1 & - & $\begin{array}{l}81.3 \\
( \pm 18.1)\end{array}$ & $58.1( \pm 33.1)$ \\
\hline Graichen et al. [11] & Prospective & 121 & 3.6 & 2 & 6.2 & - & $147( \pm 32)$ & $68.8( \pm 23.3)$ \\
\hline Jones et al. [13] & Retrospective & 15 & 4 & 2 & 6.1 & - & 134 & - \\
\hline Rosso et al. [19] & Retrospective & 51 & 4.7 & 2 & 15.1 & $\begin{array}{l}82.5 \\
( \pm 8.4)\end{array}$ & $\begin{array}{l}79.6 \\
( \pm 24.9)\end{array}$ & - \\
\hline Guo et al. [12] & Retrospective & 23 & 2.1 & 1 & 3.25 & $89( \pm 10.9)$ & - & - \\
\hline This study & Retrospective & 16 & 6.6 and 2.6 & 2 & 7.7 & $\begin{array}{l}84 \pm 11 \\
\text { and } 73 \pm \\
18\end{array}$ & $\begin{array}{l}72 \pm 22 \\
\text { and } 53 \pm \\
24\end{array}$ & $\begin{array}{l}82,5 \pm 23 \\
\text { and } 55 \pm 34\end{array}$ \\
\hline
\end{tabular}

sleeves in patients undergoing aseptic revision arthroplasty of the knee.

\section{Conclusion}

Revision arthroplasty of the knee increasingly confronts patients as well as surgeons. Large metaphyseal bone defects are of particular significance. The use of metaphyseal sleeves in patients with bone defects is a suitable instrument, which has no negative impact on outcome both in primary arthroplasty and in revision arthroplasty. Further studies with larger study groups and analysis of long-term results after use of such endoprosthetic components should be conducted.

\section{Corresponding address}

\section{Christian Lycke, M.D.}

Klinik für Orthopädie, Unfallchirurgie und Plastische Chirurgie, Universitätsklinikum Leipzig

Liebigstr. 20, 04103 Leipzig, Germany christian.lycke@medizin.uni-leipzig.de

Funding. Open Access funding enabled and organized by Projekt DEAL.

\section{Compliance with ethical guidelines}

Conflict of interest. C. Lycke, D. Zajonz, A. Brand, T. Prietzel, C.-E. Heyde, A. Roth and M. Ghanem declare that they have no competing interests.
All procedures performed in studies involving human participants or on human tissue were in accordance with the ethical standards of the institutiona and/or national research committee and with the 1975 Helsinki declaration and its later amendments or comparable ethical standards. Informed consent was obtained from all individual participants included in the study. Prior to conducting this study a positive vote of the local ethics committee was obtained (Votum No. 236/19-ek).

Open Access. This article is licensed under a Creative Commons Attribution 4.0 International License, which permits use, sharing, adaptation, distribution and reproduction in any medium or format, as long as you give appropriate credit to the original author(s) and the source, provide a link to the Creative Commons licence, and indicate if changes were made. The images or other third party material in this article are included in the article's Creative Commons licence, unless indicated otherwise in a credit line to the material. If material is not included in the article's Creative Commons licence and your intended use is not permitted by statutory regulation or exceeds the permitted use, you will need to obtain permission directly from the copyright holder. To view a copy of this licence, visit http://creativecommons.org/licenses/by/4.0/.

\section{References}

1. Agarwal S, Azam A, Morgan-Jones R (2013) Metal metaphyseal sleeves in revision total knee replacement. Bone Joint J95-B(12):1640-1644

2. Alexander GE, Bernasek TL, Crank RL, Haidukewych GJ (2013) Cementless metaphyseal sleeves used for large tibial defects in revision total knee arthroplasty. J Arthroplasty 28(4):604-607

3. Angerame MR, Jennings JM, Holst DC, Dennis DA (2019) Management of bone defects in revision total knee arthroplasty with use of a stepped, porous-coated metaphyseal sleeve. JBJS Essent Surg Tech 9(2):e14

4. Barnett SL, Mayer RR, Gondusky JS, Choi L, Patel JJ, Gorab RS (2014) Use of stepped porous titanium metaphyseal sleeves for tibial defects in revision total knee arthroplasty: short term results J Arthroplasty 29(6):1219-1224

5. Bonanzinga T, Akkawi I, Zahar A, Gehrke T, Haasper C, Marcacci M (2019) Are Metaphyseal sleeves a viable option to treat bone defect during revision total knee arthroplasty? A systematic review. Joints 7(1):19-24

6. Bozic KJ, Kurtz SM, Lau E et al (2010) The epidemiology of revision total knee arthroplasty in the United States. Clin Orthop Relat Res 468(1):45-51

7. Bugler KE, Maheshwari R, Ahmed I, Brenkel IJ, Walmsley PJ (2015) Metaphyseal sleeves for revision total knee arthroplasty: good short-term outcomes. J Arthroplasty 30(11):1990-1994

8. Dalury DF, Barrett WP (2016) The use of metaphyseal sleeves in revision total knee arthroplasty. Knee 23(3):545-548

9. Engh G (1997) Bone defect classification. Revision total knee arthroplasty. Lippincott Williams \& Wilkins, Baltimore, pp 63-120

10. Gallo J, Goodman SB, Konttinen YT, Wimmer MA, Holinka M (2013) Osteolysis around total knee arthroplasty: a review of pathogenetic mechanisms. Acta Biomater 9(9):8046-8058

11. Graichen H, Scior W, Strauch M (2015) Direct, cementless, metaphyseal fixation in knee revision arthroplasty with sleeves-short-term results. J Arthroplasty 30(12):2256-2259

12. Guo L, Du Y, Zhang M et al (2019) Short-term effectiveness of revision total knee arthroplasty with porous-coated metaphyseal Sleeve and MBT implant. Zhongguo Xiu Fu Chong Jian Wai Ke Za Zhi33(3):302-306

13. Haidukewych GJ, Hanssen A, Jones RD (2011) Metaphyseal fixation in revision total knee arthroplasty: indications and techniques. J Am Acad Orthop Surg 19(6):311-318

14. Huang R, Barrazueta G, Ong A et al (2014) Revision total knee arthroplasty using metaphyseal sleeves at short-term follow-up. Orthopedics 37(9):e804-9

15. Insall JN, Ranawat CS, Aglietti P (1976) A comparison of four models of total knee replacements prostheses. Clin Orthop Relat Res 1999:3-17

16. Jakim I, Barlin C, Sweet MB (1989) Radiological signs of loosening of the femoral stem in 
cementless total hip arthroplasty. S Afr J Surg 27(3):78-83

17. Kellgren JH, Lawrence JS, (1957) Radiological Assessment of Osteo-Arthrosis. Annals of the Rheumatic Diseases 16(4):494-502

18. Kurtz S, Ong K, Lau E, Mowat F, Halpern M (2007) Projections of primary and revision hip and knee arthroplasty in the United States from 2005 to 2030. JBone Joint Surg Am 89(4):780-785

19. Rosso F, Cottino U, Dettoni F, Bruzzone $M$, Bonasia DE, Rossi R (2019) Revision total knee arthroplasty (TKA): mid-term outcomes and bone loss/quality evaluation and treatment. J Orthop Surg Res 14(1):280

20. Sachdeva S, Baker JF, Bauwens JE et al (2019) Can revision TKA patients achieve similar clinical functional improvement compared to primaries. J Knee Surg. https://doi.org/10.1055/s-00391693415

21. Scior W, Chanda D, Graichen H (2019) Are stems redundant in times of metaphyseal sleeve fixation? J Arthroplasty 34(10):2444-2448

22. Sheth NP, Bonadio MB, Demange MK (2017) Bone loss in revision total knee arthroplasty: evaluation and management. J Am Acad Orthop Surg 25(5):348-357

23. Wang C, Pfitzner T, von Roth $\mathrm{P}$, Mayr $\mathrm{HO}$, Sostheim M, Hube R (2016) Fixation of stem in revision of total knee arthroplasty: cemented versus cementless-a meta-analysis. Knee Surg Sports Traumatol Arthrosc 24(10):3200-3211

24. Watters TS, Martin JR, Levy DL, Yang CC, Kim RH, Dennis DA (2017) Porous-coated metaphyseal sleeves for severe femoral and tibial bone loss in revision TKA. J Arthroplasty 32(11):3468-3473

25. Wengler A, Nimptsch U, Mansky T (2014) Hip and knee replacement in Germany and the USA: analysis of individual inpatient data from German and US hospitals for the years 2005 to 2011. Dtsch Arztebl Int 111(23-24):407-416

26. Wyles CC, Tibbo ME, Yuan BJ, Trousdale RT, Berry DJ, Abdel MP (2020) Long-term results of total knee arthroplasty with contemporary distal femoral replacement. JBone Joint Surg Am 102(1):45-51

Hans-Henning Epperlein, Klaus Wichmann, Andreas Deussen

\section{Funktionelles Fitnesstraining}

150 Übungen für Breiten-, Leistungssportler und Übungsleiter

Springer 2021, 2, 419 S., 930 Abb., (ISBN: 978-3-662-55332-9), Softcover 49,99 EUR

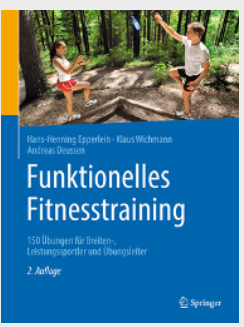

Das ,Projekt der aktiven Lebens-

führung', dem das außerordentliche Engagement der Autoren gilt, ist gerade heute durch die zunehmende Technisierung und

Digitalisierung der Umwelt von besonderer Bedeutung. Die Autoren beginnen mit einer geschichtlichen Reflexion zum Thema Bewegung und Gymnastik bei ,den alten Griechen', was zunächst befremdlich wirkt, doch durch die konsequente Fortsetzung und die differenzierte Darstellung der geschichtlichen Entwicklung des Begriffs, Gymnastik bis in die heutige Zeit werden interessante Chancen aufgezeigt, wie das funktionelle Fitnesstraining heute in den Kontext des Wirkungsverständnisses eines selbstbestimmten Lebens eingebracht werden kann. Nachdem eine prägnante und fokussierte Darstellung der anatomischen und physiologischen Grundlagen für das Verständnis der Hintergründe des funktionellen Fitnesstrainings erfolgt ist, werden diagnostische Verfahren zur Erfassung der körperlichen Fitness (Kraft, Beweglichkeit, Ausdauer) erläutert. Hierbei wird der Hintergrund des jeweiligen Testansatzes durch ansprechende Bilder und entsprechende Dokumentationsbögen verständlich, plausibel und nachvollziehbar dargestellt. Sollten bei der Durchführung der Übungen Defizite erkannt werden, verweisen die Autoren direkt auf mögliche Übungen im nachfolgenden Text. Dadurch ist es möglich zwischendurch auch einmal zielgerichtet ,querzulesen', um dann aber wieder an der Stelle weiterzulesen, bei der man aufgehört hatte.

Den Hauptteil des Buches bilden die Darlegungen zu verschiedenen Übungen des funktionellen Fitnesstrainings. Im Unterschied zu sonstigen Ansätzen werden hierbei verschiedene Trainingsorte in den Fokus genommen, neben dem klassischen Hallentraining auch Übungen im Wald oder am Strand. Dieser Wechsel der Umgebungsperspektive gibt sehr viele motivierende Impulse für ein $a b$ - wechslungsreiches Gestalten der Übungen, was für das Aufrechterhalten der Motivation der Teilnehmer*innen einen wichtigen Punkt darstellt. Die Darstellung der Übungen ist klar gegliedert und differenziert nach Schwierigkeitsgrad, Ort und beanspruchter Muskulatur. Der Fließtext des Buches wird durch alltagstaugliche ,Praxistipps' aufgelockert, die nicht nur für Einsteiger*innen in den Bereich des funktionellen Fitnesstrainings hilfreich sind Wie bereits begleiten und ergänzen die Bilder den Text hervorragend und vor allem ist in den Fotos auch der Spaß und die Freude der Personen an den Übungen festgehalten worden.

Durch die evidenzbasierte Vorgehensweise im Aufbau der Übungen und der Trainingsgestaltung leisten die Autoren mit Ihrem Buch einen wichtigen Transfer von interdisziplinären sport-, bewegungs- und gesundheitswissenschaftlichen Ansätzen in den Breiten- und Leistungssport. Die Betrachtung und der Vermittlungsansatz sind in sich konsistent und zeichnen sich durch einen hohen Praxisbezug und die durch viele Bilder sehr anschauliche Darstellungsweise aus. Das Besondere an dem vorliegenden Buch ist die stete Verknüpfung und Bezugnahme von Inhalten der verschiedenen Kapitel. Die Gliederung und die Verweise auf vorherige oder folgende Buchkapitel sind so eingebunden, dass man beim Lesen nicht den Faden verliert, sondern immer gezielt bei verschiedenen Fragestellungen (z.B. Verlust der Kraft in der Bauchmuskulatur) durch das Buch geleitet wird. So ist es ohne viele Umstände möglich, hier innerhalb von kurzer Zeit, ein entsprechendes Trainingsprogramm aufzustellen. Das Buch wird erfolgreich dazu beitragen das, Projekt der aktiven Lebensweise' mit Spaß und Freude an der Bewegung umzusetzen.

Prof. Dr. rer. nat. Klara Brixius, Neubiberg 